\title{
Low Annexin A1 level in HTLV-1 infected patients is a potential biomarker for the clinical progression and diagnosis of $\mathrm{HAM} / \mathrm{TSP}$
}

Bárbara Brasil Santana ${ }^{1,2+}$, Maria Alice Freitas Queiroz ${ }^{1 \dagger}$, Rodrigo Arcoverde Cerveira', Claudia Mendonça Rodrigues ${ }^{3}$, Ednelza da Silva Graça Amoras' ${ }^{1}$, Carlos Araújo da Costa ${ }^{4}$, Maisa Silva de Sousa ${ }^{4}$, Ricardo Ishak ${ }^{1}$, Luiz Ricardo Goulart ${ }^{3}$ and Antonio Carlos Rosário Vallinoto ${ }^{1 *}$

\begin{abstract}
Background: Human T-lymphotropic virus 1 (HTLV-1) is etiologically associated with the chronic inflammatory neurodegenerative disease HTLV-1-associated myelopathy/tropical spastic paraparesis (HAM/TSP) Annexin A1 (AnXA1) is an anti-inflammatory protein with proposed neuroprotective and anti-neuroinflammatory functions. We hypothesized that ANXA1 gene expression may be dysregulated in HTLV-1-infected HAM/TSP patients.

Methods: This study involved 37 individuals infected with HTLV-1, including 21 asymptomatic (AS) carriers and 16 with HAM/TSP, and a control group of 30 individuals negative for HTLV-1 and HTLV-2. For AS HTLV-1-positive and HAM/TSP patients, ANXA1 and formyl peptide receptor (FPR1, FPR2 and FPR3) expression and HTLV-1 proviral load $(P V L)$ in peripheral blood cells were evaluated by real-time quantitative PCR ( $(P C R)$, and plasma AnxA1 levels were determined by enzyme-linked immunosorbent assay (ELISA).

Results: ANXA1 gene expression was increased in the AS group compared with the HAM/TSP and control groups, but the differences were not statistically significant. FPR1 gene expression was higher in patients with HTLV-1 than in controls (AS, $p=0.0032$; HAM/TSP, $p<0.0001$ ). Plasma AnxA1 levels were higher in the AS group than in the HAM/TSP group ( $p=0.0045)$, and PVL was higher in patients with HAM/TSP than in AS individuals $(p=0.0162)$. The use of a combined ROC curve using Annexin 1 levels and proviral load significantly increased the sensitivity and specificity to predict progression to HAM/TSP (AUC $=0.851$ and $A \cup C=0.937$, respectively, to AUC $=1000$ ).
\end{abstract}

Conclusions: Our results suggest that AnXA1 may be dysregulated in HAM/TSP patients. Serological detection of AnxA1 in association with proviral load may provide a prognostic biomarker for HTLV-1-associated neurodegenerative disease.

Keywords: Annexin A1, HTLV, HAM/TSP, Infection, Biomarker

\footnotetext{
* Correspondence: vallinoto@me.com

†'Bárbara Brasil Santana and Maria Alice Freitas Queiroz contributed equally to this work.

'Laboratório de Virologia, Instituto de Ciências Biológica, Universidade Federal do Pará, Belem 66.075-110, Brazil

Full list of author information is available at the end of the article
}

(c) The Author(s). 2021 Open Access This article is licensed under a Creative Commons Attribution 4.0 International License, which permits use, sharing, adaptation, distribution and reproduction in any medium or format, as long as you give appropriate credit to the original author(s) and the source, provide a link to the Creative Commons licence, and indicate if changes were made. The images or other third party material in this article are included in the article's Creative Commons. licence, unless indicated otherwise in a credit line to the material. If material is not included in the article's Creative Commons licence and your intended use is not permitted by statutory regulation or exceeds the permitted use, you will need to obtain permission directly from the copyright holder. To view a copy of this licence, visit http://creativecommons.org/licenses/by/4.0/ The Creative Commons Public Domain Dedication waiver (http://creativecommons.org/publicdomain/zero/1.0/) applies to the data made available in this article, unless otherwise stated in a credit line to the data. 


\section{Background}

Human T-lymphotropic virus 1 (HTLV-1) is a member of the family Retroviridae, subfamily Orthoretrovirinae, genus Deltaretrovirus [1] that is endemic in Japan, the Caribbean, South America, Sub-Saharan Africa and Melanesia [2]. HTLV-1 infection is associated with adult $\mathrm{T}$ cell leukemia/lymphoma (ATLL), mature $\mathrm{CD} 4^{+} \mathrm{T}$ cell neoplasms, and HTLV-1-associated myelopathy/tropical spastic paraparesis (HAM/TSP), a chronic and progressive neurodegenerative disease $[3,4]$.

HAM/TSP is a chronic, progressive, demyelinating disease that affects the spinal cord and brain white matter, leading to the onset of a severe clinical syndrome involving motor impairment of the lower limbs [4]. The clinical picture begins and evolves insidiously, and it is often impossible to establish the initial onset of symptoms [5].

Several studies have identified Tax regulatory protein as the main target of the immune response against HTLV-1, as this antigen is most efficiently recognized by cytotoxic T lymphocytes [6-9]. HTLV-1 infection induces the activation and robust proliferation of infected $\mathrm{T}$ lymphocytes. This phenomenon is mainly related to the function of the viral tax gene, which is involved in transactivation of the interleukin-2 (IL-2) and IL-2 receptor genes, among others [10]. Indiscriminate cell proliferation can also lead to the expansion of self-reactive $\mathrm{T}$ cells and the marked secretion of proinflammatory cytokines, such as tumor necrosis factor alpha (TNF- $\alpha$ ). These abnormalities are associated with the neurological damage observed in patients with HAM/TSP [11].

Based on the recognition that a sustained systemic inflammatory response contributes to chronic neurodegenerative disorders, we hypothesized that the antiinflammatory response may be dysfunctional in HAM/ TSP patients. Among many anti-inflammatory molecules, annexin A1 (AnxA1) likely plays an important role in modulating neuroinflammation triggered by both resident glial cells as part of the innate immune system in the brain and circulating leukocytes that breach the blood-brain barrier [12]. AnxA1, a 37-kDa protein that belongs to the annexin superfamily [13, 14], has been identified as a glucocorticoid-induced anti-inflammatory protein involved in eicosanoid and phospholipase A2 synthesis $[15,16]$. The secretion of AnxA1 is key for anti-inflammatory activity, as this protein binds in an autocrine or paracrine manner to specific receptors on the outer leaflet of the plasma membrane of target cells, reducing proinflammatory activity [17-19]. AnxA1 receptor (formyl peptide receptor: FPR1, FPR2 and FPR3) expression is particularly high on the plasma membranes of macrophages, monocytes and neutrophils [19-22].

Thus, considering that HAM/TSP is a systemic immune disorder caused by Th1 cell activation and increased levels of proinflammatory cytokines, we hypothesized that AnxA1 is dysfunctional in this context, which may impact its neuroprotective immunomodulatory role. Therefore, the present work investigated the associations of $A N X A 1$ gene expression profiles and protein levels with the development of HAM/TSP.

\section{Methods}

\section{Case sample}

A total of 57 individuals participated in this study and were divided into the following groups:

Group 1 (asymptomatic, AS): 21 AS HTLV-1 carriers who were positive by enzyme-linked immunosorbent assay (ELISA) and real-time quantitative polymerase chain reaction (qPCR).

Group 2 (HAM/TSP): 16 HTLV-1 carriers who were by positive ELISA and real-time PCR with a clinically confirmed HAM/TSP diagnosis.

Group 3 (control group, CG): 20 individuals negative for HTLV-1 and HTLV-2 by serological and molecular tests.

The clinical classification of patients was performed by a neurologist at the Tropical Medicine Center (NMT) in Belém, State of Pará, Brazil, following the protocol of De Castro-Costa et al. [23]. The main clinical symptoms diagnosed in the HAM/TSP group were low back pain, constipation, leg weakness, increased deep reflexes, bladder disturbance, cramps and Babinski's sign. Blood samples were collected between August 2015 and May 2017 at the NMT, and laboratory procedures were conducted at the Laboratory of Virology (LabVir) of the Federal University of Pará (UFPA). Blood samples (5 mL) obtained by venipuncture were placed in 2 vacutainers containing ethylenediaminetetraacetic acid (EDTA) as an anticoagulant and were used for flow cytometry, ribonucleic acid (RNA) extraction and plasma AnxA1 measurements. All subjects were seronegative for human immunodeficiency virus 1 (HIV-1). HAM/TSP patients were not on anti-inflammatory treatment at the time of the study.

\section{RNA extraction, quantification and reverse transcription} RNA was extracted from whole blood cells using TRIzol ${ }^{\circ}$ reagent (Applied Biosystems, Foster City, CA, USA) following the manufacturer's protocol. RNA was quantified in the SpectraMax ${ }^{\odot}$ i3 Multi-Mode Detection Platform, which uses a 24-well microplate containing $2 \mu \mathrm{L}$ of elution buffer in one well as a blank and $2 \mu \mathrm{L}$ of each sample in the other wells. The absorbance of the samples was read at a wavelength of $260 \mathrm{~nm}$. Then, $20 \mathrm{ng}$ of deoxyribonuclease I (DNase I)-treated RNA was used for the reverse transcription of messenger RNA (mRNA) into complementary DNA (cDNA) using the High Capacity cDNA Reverse Transcription kit (Applied 
Biosystems, USA), following the manufacturer's technical recommendations. The cDNA was stored at $20{ }^{\circ} \mathrm{C}$ prior to use.

\section{ANXA1, FPR1, FPR2 and FPR3 gene expression}

CDNA was analyzed using real-time quantitative PCR (relative quantification (RQ) by the $\Delta \Delta C \mathrm{~T}$ method). The qPCR results for endogenous genes and targets were standardized to calculate the efficiency of the amplification reactions. Different concentrations of cDNA were tested (undiluted and 4 serial dilutions using a factor of 2 , from $1: 2$ to $1: 16)$. Reactions were performed in triplicate wells and analyzed simultaneously using the same cDNA (at different dilutions) with different probes to construct an efficiency curve and validate the $2^{-\Delta \Delta C T}$ analysis method. All assays showed the expected efficiency (100 $\pm 10 \%$; Supplementary Fig. 1$)$. The RQ of target gene expression was conducted based on the comparative CT method $(\Delta \Delta \mathrm{CT})$ using the $2^{-\Delta \Delta C T}$ formula, where $\Delta \Delta \mathrm{CT}=\Delta \mathrm{CT}_{\text {sample }}-\Delta \mathrm{CT}_{\text {reference }} \quad$ [24]. $A N X A 1, F P R 1, F P R 2$ and FPR3 mRNA levels were quantified using GoTaq Green Master Mix (Promega, Madison, WI, USA) with $\beta$-actin as the reference gene. The reactions were carried out in the StepOne PLUS Sequence Detector (Applied Biosystems, Foster City, CA, USA). The primer sequences are provided in Table 1. The reactions included 1X GoTaq Green Master Mix $[2 \mathrm{X}], 0.5 \mathrm{pmol} / \mu \mathrm{L}$ primer $[10 \mathrm{pmol} / \mu \mathrm{L}]$ and $60 \mathrm{ng}$ of cDNA in a final reaction volume of $20 \mu \mathrm{L}$. The temperature conditions were as follows: $95^{\circ} \mathrm{C}$ (hold stage) for $20 \mathrm{~s}$, followed by 40 cycles of $95^{\circ} \mathrm{C}$ (denaturation) for $15 \mathrm{~s}$ and $60{ }^{\circ} \mathrm{C}$ (primer binding and product extension) for $20 \mathrm{~s}$. The melting curves for all the samples were evaluated after the reaction ended, and those for the investigated genes are presented in Supplementary Fig. 2.

Table 1 Nucleotide sequences of the primers used for real-time PCR to quantify ANXA1, FPR1, FPR2 and FPR3 mRNA levels

\begin{tabular}{lll}
\hline Primer & Sequence (5'-3') & Direction \\
\hline ANXA1F & GATTTTCGGACGCTTGCT & Forward \\
ANXA1R & AGTCCTCAGATCGGTCACCCT & Reverse \\
FPR1F & ACCCAGAGCAAGACCACAGC & Forward \\
FPR1R & TCCATCTTGTCTGCTCCTGCA & Reverse \\
FPR2F & ATTTGCAGCCTTGAGGTCA & Forward \\
FPR2R & AGCACCTGGTGCATITCCT & Reverse \\
FPR3F & GGATGACACGCACAGTCAACA & Forward \\
FPR3R & TCAGCTAGGGCCAGGTTCAG & Reverse \\
BACTINAF & TCCCTGGAGAAGAGCTACG & Forward \\
BACTINAR & TAGTTTCGTGGATGCCACA & Reverse \\
\hline
\end{tabular}

\section{Quantification of plasma AnxA1 levels}

Plasma AnxA1 levels were measured by ELISA (Human Annexin A1 ELISA Kit, ab222868, Abcam, Cambridge, UK) with specific polyclonal anti-human AnxA1 antibodies. The assays were conducted according to the manufacturer's recommendations.

\section{Quantification of HTLV-1 proviral load}

Proviral load (PVL) was quantified by qPCR using three target sequences synthesized using the TaqMan ${ }^{\circledR}$ system (Life Technologies, Foster City, CA, USA) according to a previously described protocol [25]. The results were adjusted to obtain the absolute proviral quantification considering the leukocyte count per $\mathrm{mm}^{3}$, and the final results are presented as DNA proviral copies $/ \mathrm{mm}^{3}$.

\section{Statistical analysis}

Normality analysis of the sample distribution was performed using the Kolmogorov-Smirnov test. Target gene expression levels and the percentages of ANXA1-expressing immunoinflammatory cells were compared among groups using the nonparametric Kruskal-Wallis test. Significant results in the Kruskal-Wallis test were subjected to multiple comparisons analysis by Dunn's post test. Plasma AnxA1 levels and PVL were compared between the HAM/TSP and AS groups by the MannWhitney test. Receiver operating characteristic (ROC) curves were made to investigate diagnostic accuracy in the PVL, AnxA1 and PVL + AnxA1 tests in relation to sensitivity and specificity. The area under the ROC curve (AUC) represents the ability of the test to correctly classify participants with HAM/TSP and progression to disease. The AUC values vary between 1 (diagnosis correctness) and 0 (diagnosis error). The tests were performed using BioEstat 5.3 software [26] and the ROC curve analyzes were performed by the programs GraphPad prism 6.0 and SSP 25.0. The results with $p<0.05$ were considered significant.

\section{Results}

Standard curves generated to calculate the amplification efficiency and melting curves for the target genes are shown in Figs. S1 and S2, respectively. Quantification of ANXA1, FPR1, FPR2 and FPR3 gene expression levels in the investigated groups showed lower $A N X A 1$ mRNA levels in the controls than in the HTLV-1-infected individuals, but these differences were not significant. Among the infected patients, those with HAM/TSP expressed lower ANXA1 levels (Fig. 1a). The mean $\mathrm{Ct}$ values for the reference and target genes in each group are shown in Table $\mathrm{S} 1$.

FPR1 gene expression levels were significantly lower in the control individuals than in those infected with 

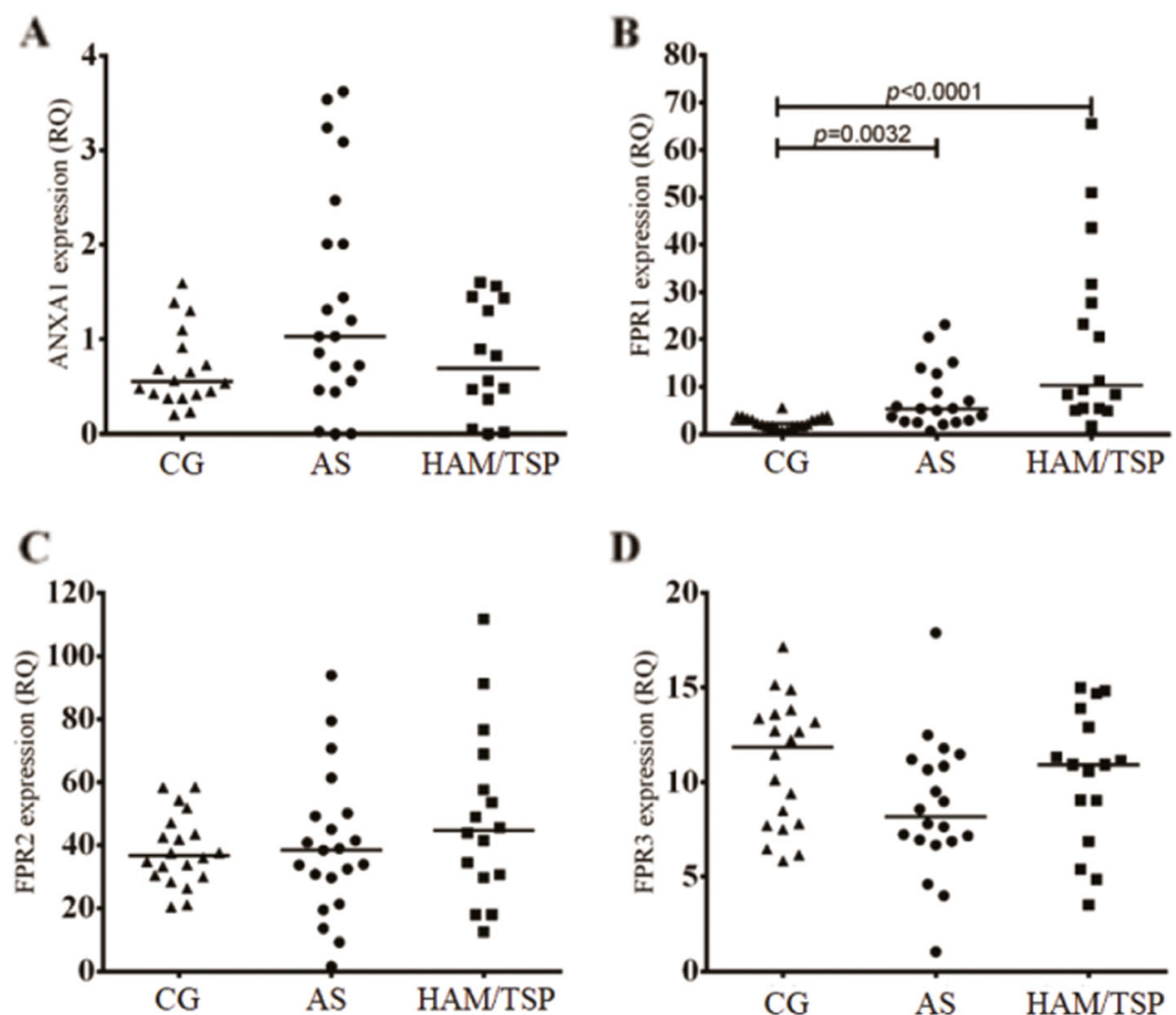

D

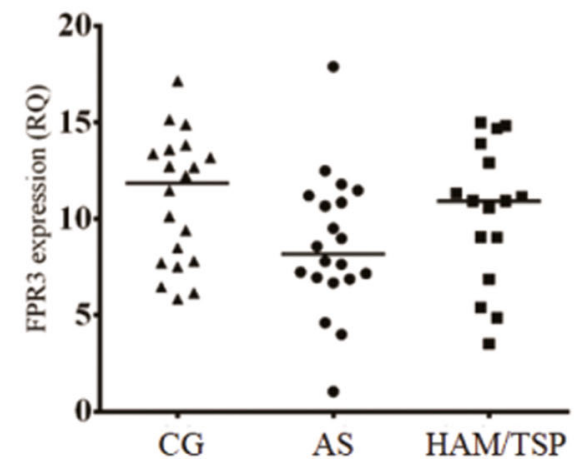

Fig. 1 Quantification of (a) ANXA1, (b) FPR1, (c) FPR2 and (d) FPR3 mRNA levels in whole blood from the control group (CG), asymptomatic (AS) patients and patients diagnosed with HTLV-1-associated myelopathy/tropical spastic paraparesis (HAM/TSP). RQ: relative quantification. *Median (Kruskal-Wallis test)
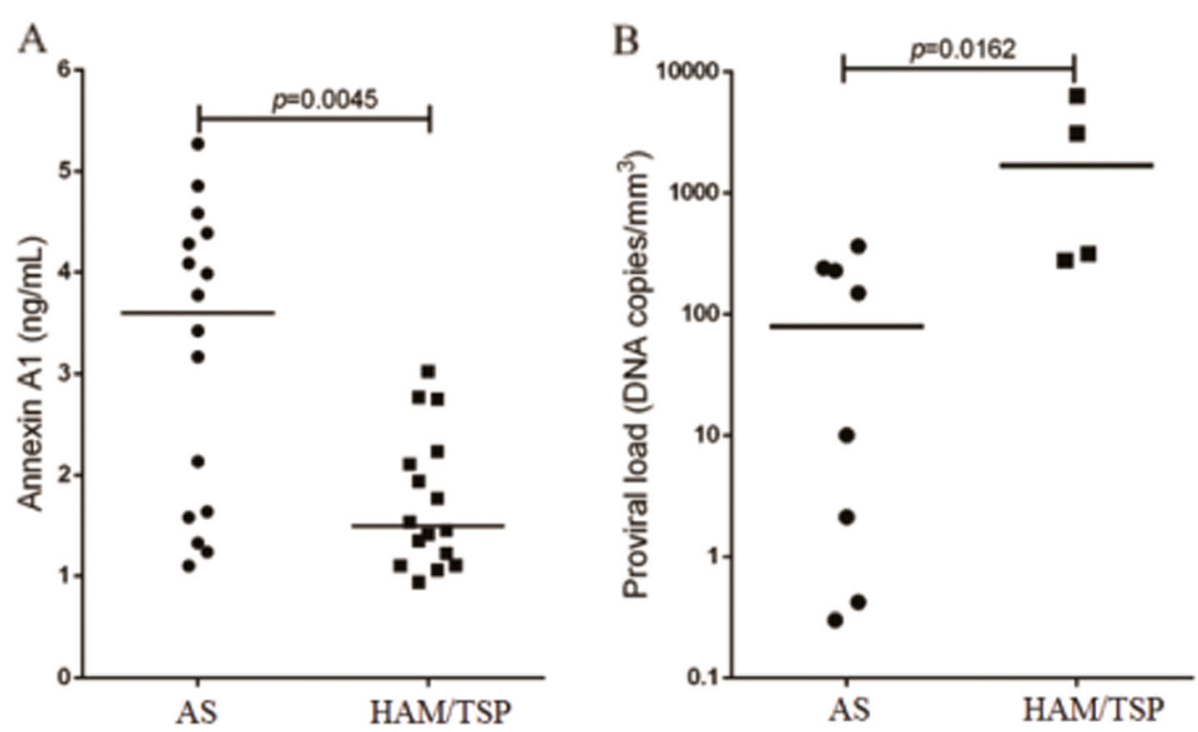

Fig. 2 Quantification of (a) annexin A1 (AnxA1) plasma levels and (b) human T-lymphotropic virus 1 (HTLV-1) proviral load in asymptomatic (AS) patients and patients diagnosed with HTLV-1-associated myelopathy/tropical spastic paraparesis (HAM/TSP). *Median (Mann-Whitney test) 
Table 2 Evaluation of the sensitivity and specificity of the dosages of Annexin and Proviral Load as biomarkers in the prognosis of HTLV-1 infection

\begin{tabular}{lllllll}
\hline Variable & AUC & P value & Cut-off & $\begin{array}{l}\text { Sensitivity } \\
\%(C l \%)\end{array}$ & $\begin{array}{l}\text { Specificity } \\
\%(C l \%)\end{array}$ \\
\hline Annexin A1 & 0.851 & 0.0006 & $<3.095$ & $100(79.41-100)$ & $62.50(35.43-84.80)$ & 2.667 \\
Proviral load & 0.937 & 0.0174 & $>259.5$ & $100(39.76-100)$ & $87.50(43.75-99.68)$ & 8.000 \\
\hline
\end{tabular}

AUC Area under the ROC Curve, LR Likelihood ratio

HTLV-1 (Fig. 1b). FPR2 and FPR3 expression levels were not different among the groups (Fig. $1 \mathrm{c}$ and d).

Serum AnxA1 levels were evaluated to assess whether the observed mRNA expression profiles reflect the amount of free AnxA1 in plasma. The AS group had significantly higher serum AnxA1 levels than the HAM/ TSP group ( $p=0.0045$, Fig. 2a). In contrast, the PVL was significantly higher $(p=0.0162)$ in the HAM/TSP patients than the AS individuals (Fig. 2b).

The levels of Annexin A1 and proviral load were evaluated using the ROC curve to identify the potential of these markers as adjunct laboratory diagnostics for the identification of patients with HAM/TSP. Table 2 shows that the two tests had an area on the curve (AUC) of 0.8516 and 0.9375 , respectively. The sensitivity of both fixed at $100 \%$ allowed to reach specificity levels of 62.5 and $87.5 \%$, respectively. The value of the best cut-off point for the identification of patients with HAM/TSP was $<3095$ for annexin A1 and $>259.5$ for proviral load. The best points of the curves are shown in Fig. 3 a and b.

The use of the ROC curve principle, combining the two variables, in order to improve the prediction of asymptomatic progression to HAM/TSP, showed that sensitivity and specificity reached high levels, close to $100 \%$ (Table 3). Table S2 show the list of HTLV-1 infected subjects and their Annexin A1 and proviral load

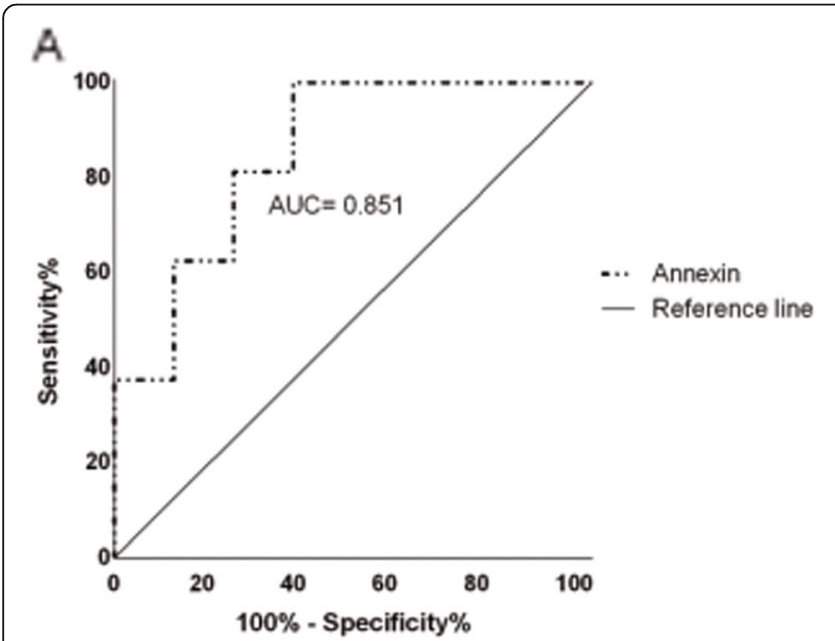

Fig. 3 ROC curve of (a) Annexin A1 and (b) Proviral Load levels. Figure 4 shows the representation of the performance of the investigated markers.

\section{Discussion}

The molecular mechanisms underlying the progressive neurodegeneration that characterizes the pathogenesis of HAM/TSP in HTLV-1-infected patients continue to be discussed by researchers. In this investigation, we suggest an association between the reduced ANXA1 expression with the possible lack of an anti-inflammatory response in HAM/TSP HTLV-1-infected patients, who are characterized by a sustained systemic inflammatory response and a high PVL that contribute to chronic neurodegenerative disease.

The host genotype (determined mainly by the human leukocyte antigen (HLA) class I and killer cell immunoglobulin-like receptor (KIR) loci), quality of the cytotoxic $\mathrm{T}$ cell (CTL) response against HTLV-1infected cells, $\mathrm{T}$ regulatory cell (Treg) frequency (forkhead box protein $3(\text { FOXP3) })^{+}$) and PVL are important risk factors for the development of TSP/HAM [27-29]. An important prognostic factor for the development of HTLV-1-associated diseases is the PVL in blood as assessed by qPCR $[30,31]$. AS carriers tend to have a lower PVL than those who develop HAM/TSP [32, 33].

Given the debate regarding the factors that affect HAM/TSP pathogenesis, in the present study, we investigated the potential association of AS HTLV-1 infection

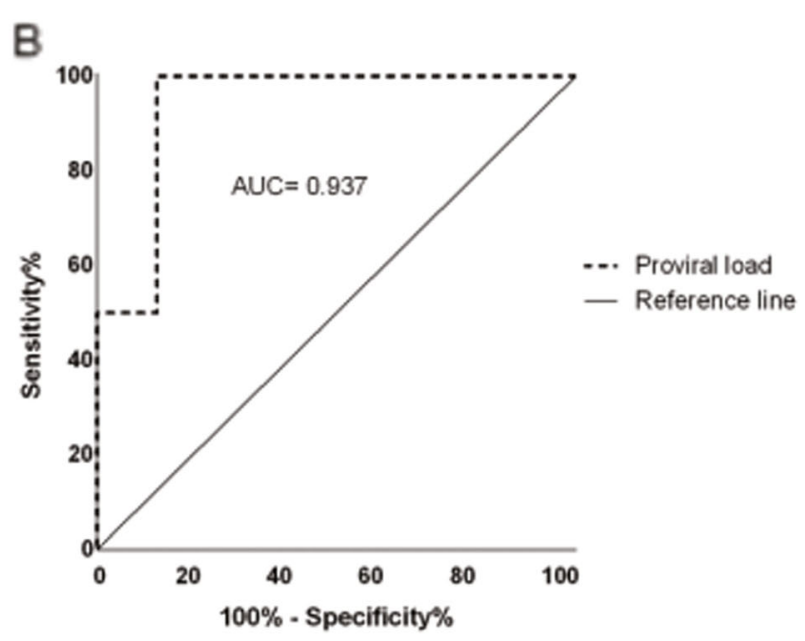


Table 3 Assessment of Annexin and Proviral Load used simultaneously to estimate the progression and diagnostic confirmation of HAM/TSP

\begin{tabular}{lllll}
\hline Test & AUC & $\boldsymbol{P}$ value & Sensitivity \% & Specificity \% \\
\hline Annexin A1 (AnxA1) & 0.875 & 0.042 & 100 & 75 \\
Proviral load (PL) & 0.938 & 0.017 & 100 & 87.50 \\
AnxA1 + PL & 1.000 & 0.007 & 100 & 100 \\
\hline
\end{tabular}

AUC Area under the ROC Curve

or infection with HAM/TSP symptoms and the gene expression of ANXA1 and its receptors (FPRs) in peripheral blood cells. The results showed that AS individuals had higher ANXA1 mRNA levels, which might suggest that AnxA1 is an important factor controlling the inflammatory response that triggers HTLV-1-associated neurodegenerative disease. A previous study suggested that AnxA1 is a potential biomarker for the advanced stage of cell transformation, which is directly linked to the uncontrolled growth of infected cells, accumulation of genetic defects and development of symptoms of HTLV-1-associated diseases [34]. However, the pathophysiology of HAM/TSP has an inflammatory nature that is different from HTLV-1-induced cell transformation, and therefore, it would not be hard to assume that the high endogenous production of the antiinflammatory protein AnxA1 could have a protective effect on the progression of HAM/TSP.

In addition to the association between ANXA1 mRNA transcription and HTLV-1 infection, a relationship was observed between infection and FPR mRNA levels. The interactions of these receptors with other ligands (both anti- and proinflammatory) enable the regulation of several pathological conditions, including tumorigenesis $[35,36]$, inflammation [37] and some infectious processes [38].
We observed that the HTLV-1 carriers with HAM/ TSP symptoms had higher FPR1 mRNA levels than HTLV-1-infected AS subjects and controls. Although these data suggest a relationship between FPR1 and the pathogenesis of HAM/TSP in HTLV-1-infected patients, the evidence remains preliminary, and further mechanistic studies are necessary. Additional studies must be performed to confirm whether the higher viral load somehow triggers increased FPR1 levels through another receptor or if the lower AnxA1 levels induce FPR1 expression.

We evaluated serum AnxA1 levels to assess whether the mRNA expression profile reflects free annexin levels in plasma. The quantification showed high AnxA1 plasma levels in AS patients than in HAM/TSP patients, inverse to the PVL results. Although a direct correlation between annexin and PVL (data not shown) was not observed in the present study, AnxA1 seems to be a potential new biomarker that, in addition to PVL, could contribute to the follow-up of HTLV-1-infected subjects, but longitudinal data are required among people with asymptomatic HTLV-1 infection to confirm our hypothesis.

Although the study was cross-sectional and does not do a mechanistic analysis, the results seem to suggest an anti-inflammatory role of AnxA1 in HTLV-1 infection, what if confirmed, could be neuroprotective, since patients with higher levels of this protein could better control the development of HAM/TSP. Thus, the possible antiviral activity of AnxA1 against HTLV-1 must be more thoroughly investigated.

\section{Conclusions}

In conclusion, taken together the quantification of Anexin and proviral load quantification, could be an

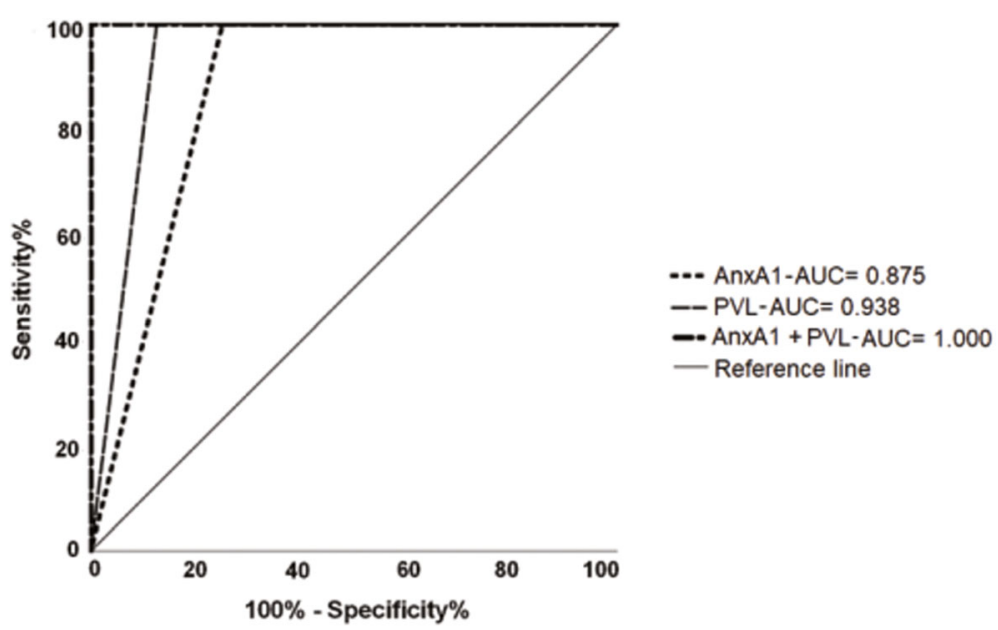

Fig. 4 ROC curve of the Annexin A1 and Proviral Load markers used simultaneously to predict progression and diagnostic confirmation of HAM/TSP. 
important laboratory tool to aid in the diagnosis of HAM/TSP. Even though the sample used herein was small, which is always a big problem in the study of HTLV-1, the periodic clinical assessment of HTLV-1 carriers associated with the quantitative analysis of Annexin and proviral load, as used in the present study, seems to be of relevance in the prognostic prediction of the progression of asymptomatic infection to HAM/TSP, considering the high sensitivity and specificity values found. However, we highlight the need of populationbased and longitudinal cohort studies aiming to define cut-offs for serum AnxA1 levels among different groups as differential diagnostic criteria and so to confirm our hypothesis.

\section{Supplementary Information}

The online version contains supplementary material available at https://doi. org/10.1186/s12879-021-05917-y.

Additional file 1.

\section{Abbreviations}

HTLV-1: Human T-Lymphotropic virus 1 (HTLV-1); HAM/TSP: HTLV-1associated myelopathy/tropical spastic paraparesis; AnxA1: Annexin A1; PVL: Proviral load; FPR: Formyl peptide receptor; ELISA: Enzyme-linked immunosorbent assay; qPCR: Real-time quantitative polymerase chain reaction; ATLL: Adult T cell leukemia/lymphoma; IL-2: Interleukin-2; TNFa: Tumor necrosis factor alpha; AS: Asymptomatic; CG: Control group; NMT: Tropical Medicine Center; LabVir: Laboratory of Virology; DNAse: Deoxyribonuclease; cDNA: Complementary DNA; EDTA: Ethylenediaminetetraacetic acid; RNA: Ribonucleic acid; mRNA: Messenger ribonucleic acid; HIV-1: Human immunodeficiency virus 1; HLA: Human leukocyte antigen; KIR: Killer cell immunoglobulin-like receptor; CTL: Cytotoxic T cell; Treg: T regulatory cell; FOXP3: Forkhead box protein 3

\section{Acknowledgments}

We thank all of the patients who accepted the opportunity to participate in the present study.

\section{Authors' contributions}

ACRV and LRG designed the study. ACRV and LRG were the general coordinators of the project. BBS, CMR, ESGA, MSS, CAC and RAC provided technical assistance and performed the experiments. BBS and MAFQ analyzed all data. ACRV and RI wrote the manuscript with input from al authors. LRG revised the manuscript. All authors read and approved the final manuscript.

\section{Funding}

The study was funded by the Brazilian National Council for Scientific and Technological Development (CNPq; \#301869/2017-0; \#312979/2018-5), Amazon Research Foundation (Fapespa; \#156/2014), National Institute of Science and Technology in Theranostics and Nanobiotechnology (INCTTeraNano; CNPq/CAPES/FAPEMIG, grant numbers CNPq-465669/2014-0 and FAPEMIG-CBB-APQ-03613-17) and Federal University of Pará (PROPESP/PAPQ 2018).

\section{Availability of data and materials}

The datasets in this study are available from the corresponding author on reasonable request.

\section{Ethics approval and consent to participate}

The present study was approved by the Human Research Ethics Committee of the Federal University of Pará (opinion 956.258) following the Guidelines and Standards Regulating Human Research (Resolution 196 of the Brazilian
National Health Council). Individuals who agreed to participate in the study signed an informed consent form.

\section{Consent for publication}

No applicable.

\section{Competing interests}

The authors declare that they have no competing interests.

\section{Author details}

${ }^{1}$ Laboratório de Virologia, Instituto de Ciências Biológica, Universidade Federal do Pará, Belem 66.075-110, Brazil. ${ }^{2}$ Graduate Program in Biology of Infectious and Parasitic Agents, Biological Science Institute, Federal University of Pará, Belem 66.075-110, Brazil. ${ }^{3}$ Laboratory of Nanobiotechnology, Biotechnology Institute, Federal University of Uberlândia, Uberlândia 38.400-902, Brazil. ${ }^{4}$ Laboratory of Cellular and Molecular Biology, Tropical Medicine Center, Federal University of Pará, Belem 66.055-240, Brazil.

Received: 18 December 2020 Accepted: 11 February 2021

Published online: 25 February 2021

\section{References}

1. ICTV. The Universal Virus Database of the International Committee on Taxonomy of Viruses, Budapest, Hungria. 2016. https://talk.ictvonline.org/ taxonomy/. Accessesd 17 Dec 2019

2. Cassar O, Gessain A. Serological and molecular methods to study epidemiological aspects of human T-cell lymphotropi vírus type 1 infection. Methods Mol Biol. 2017:1582:3-24.

3. Hinuma Y, Komoda H, Chosa T, Kondo T, Kohakura M, Takenaka T, et al. Antibodies to adult T-cell leukemia-virus-associated antigens (ATLA) in sera from patients with ATL and controls in Japan: a nation-wide seroepidemiologic study. Int J Cancer. 1982;29:631-5.

4. Osame M, Usuku K, Izumo S. HTLV-I associated myelopathy, a new clinical entity. Lancet. 1986;1:1031-2.

5. Ribas JGR, Melo GCN. Mielopatia associada ao vírus linfotrópico humano de células T do tipo 1 (HTLV-1). Rev Soc Bras Med Trop. 2002;35:377-84.

6. Jacobson S, Gupta A, Mattson D, Mingioli E, McFarlin DE. Immunological studies in tropical spastic paraparesis. Ann Neurol. 1990;27:149-56.

7. Kanagi M, Shida $\mathrm{H}$, Igarashi $\mathrm{H}$, Kuruma $\mathrm{K}$, Murai $\mathrm{H}$, Aono $\mathrm{Y}$, et al. Target epitope in the tax protein of human T- cell leucemia vírus type I recognized by class I major histocompatiblity complex- restricted cytotoxic T cells. J Virol. 1992:66:2928-33.

8. Parker CE, Daenke SD, Nightingale S, Bangham CRM. Activated HTLVI speci ¿c cytotoxic Tcells are found in healthy seropositives as well as patients with tropical spastic paraparesis. Virology. 1992;188:628-36.

9. Goon PKC, Bangham CRM. Interference with immune function by HTLV-1. Clin Exp Immunol. 2004;137:234-6.

10. Boxus M, Willems L. Mechanisms oh HTLV-1 persistence and transformation. Br J Cancer. 2009;101:1497-501.

11. Barmak K, Harhaj EW, Wigdahl B. Mediators of central nervous system damage during the progression of human T-cell leukemia type l-associated myelopathy/tropical spastic paraparesis. J Neuro-Oncol. 2003;9:522-9.

12. Solito E, McArthur S, Christian H, Gavins F, Buckingham JC, Gillies GE. Annexin A1 in the brain - undiscovered roles? Trends Pharmacol Sci. 2008, 29:135-42.

13. Pepinsky RB, Tizar D, Mattaliano RJ, Sinclair LK, Miller GT, Browning JL, et al. Five distinct calcium and phospholipid binding proteins share homology with lipocortin I. J Biol Chem. 1988;263:10799-811.

14. Raynal P, Pollard H. Annexins: the problem of assessing the biological role for a gene family of multifunctional calcium- and phospholipid-binding proteins. Biochim Biophys Acta. 1994;1197:63-93.

15. Flower RJ, Blackwell GJ. Anti-inflammatory steroids induce biosynthesis of a phospholipase A2 inhibitor which prevents prostaglandina generation. Nature. 1997;278:456-9.

16. Flower RJ. Lipocortin and the mechanism of action of the glucocorticoids. Br J Pharmacol. 1988:94:987-1015.

17. Buckingham JC, Flower RJ. Lipocortin 1: a second messenger of glucocorticoid action in the hypothalamo-pituitary-adrenocortical axis. Mol Med Today. 2997;3:296-302. 
18. Taylor AD, Philip JG, John CD. Annexin 1 (lipocortin 1) mediates the glucocorticoid inhibition of cyclic adenosine 3',5'-monophosphatestimulated prolactin secretion. Endocrinology. 2000;141:2209-19.

19. Yang $Y$, Hutchinson P, Morand EF. Inhibitory effect of annexin I on synovial inflammation in rat adjuvant arthritis. Arthritis Rheum. 1999;42:1538-44.

20. Goulding NJ, Guyre PM. Regulation of inflammation by lipocortin 1. Immunol Today. 1992;13:295-7.

21. Goulding NJ, Pan L, Wardwell K, Guyre VC, Guyre PM. Evidence for specific annexin I-binding proteins on human monocytes. Biochem J. 1996;316:593-7.

22. Perretti M, Flower RJ. Measurement of lipocortin 1 levels in murine peripheral blood leukocytes by flow cytometry: modulation by glucocorticoids and inflammation. Br J Pharmacol. 1996;118:605-10.

23. De Castro-Costa CM, Araújo AQ, Barreto MM, Takayanagui OM, Sohler MP, da Silva EL, et al. Proposal for diagnostic criteria of tropical spastic paraparesis/HTLV-I-associated myelopathy (TSP/HAM). AIDS Res Hum Retrovir. 2006;22:931-5.

24. Livak KJ, Schmittgen TD. Analysis of relative gene expression data using real-time quantitative PCR and the 2(-Delta Delta C(T)) method. Methods. 1992:25:402-8

25. Tamegão-Lopes BP, Rezende PR, Maradei-Pereira LM, de Lemos JA. HTLV-1 and HTLV-2 proviral load: a simple method using quantitative real-time PCR. Rev Soc Bras Med Trop. 2006;39:548-52.

26. Ayres M, Ayres JR, Ayres DL, Santos AS. BioEstat 5.3: aplicações estatísticas nas áreas das Ciências Biológicas e Médicas. Belém: Editora Sociedade Civil Mamirauá; 2011. p. 364p.

27. Jeffery KJ, Usuku K, Hall SE, Matsumoto W, Taylor GP, Procter J, et al. HLA alleles determine human T-lymphotropic virus-I (HTLV-I) proviral load and the risk of HTLV-l-associated myelopathy. Proc Natl Acad Sci U S A. 1999;96: 3848-53.

28. Hanon E, Halls S, Taylor GP, Saito M, Davis R, Tanaka Y, et al. Abundant tax protein expression. InCD4+ T cells infected with human T-cell lymphotropic vírus type I (HTLV-I) is prevented by cytotoxic T lymphocytes. Blood. 2000; 95:1386-92.

29. Ghezeldasht SA, Sadeghian H, Azarpazhooh MR, Shamsian SAA, Rafatpanah H, Mahmoodi M, Rezaee SA. Evaluation of T regulatory lymphocytes transcription factors in HTLV-1-associated myelopathy/tropical spastic Paraparesis (HAM/TSP) patients. Appl Biochem Biotechnol. 2017;182:1403-14.

30. Akbarin MM, Rahimi H, Hassannia T, Shoja Razavi G, Sabet F, Shirdel A. Comparison of HTLV-I Proviral load in adult T cell leukemia/lymphoma (ATL), HTLV-I-associated myelopathy (HAM-TSP) and healthy carriers. Iran J Basic Med Sci. 2013;16:208-12.

31. Nagai M, Usuku K, Matsumoto W, Kodama D, Takenouchi N, Moritoyo T, et al. Analysis of HTLV-I proviral load in 202 HAM/TSP patients and 243 asymptomatic HTLV-I carriers: high prociral load strongly predisposes to HAM/TSP. J Neuro-Oncol. 1998;4:586-93.

32. Izumo S, ljichi T, Higuchi I, Tashiro A, Takahashi K, Osame M. Neuropathology of HTLV-I-associated myelopathy--a report of two autopsy cases. Acta Paediatr Jpn. 1992;34:358-64.

33. Goon PK, Hanon E, lgakura T, Tanaka Y, Weber JN, Taylor GP, Bangham CR. High frequencies of Th1-type CD4(+) T cells specific to HTLV-1 Env and tax proteins in patients with HTLV-1-associated myelopathy/tropical spastic paraparesis. Blood. 2002;99:3335-41.

34. Chen Z, Yoshihara E, Son A, Matsuo Y, Masutani H, Sugie K, et al. Differential roles of Annexin A1 (ANXA1/lipocortin-1/lipomodulin) and thioredoxin binding protein-2 (TBP-2NDUP1/TXNIP) in glucocorticoid signaling of HTLVI-transformed T cells. Immunol Lett. 2010;131:11-8.

35. Gastardelo TS, Cunha BR, Raposo LS, Maniglia JV, Cury PM, Lisoni FC, et al. Inflammation and cancer: role of annexin A1 and FPR2/ALX in proliferation and metastasis in human laryngeal squamous cell carcinoma. PLoS One. 2014;9:e111317.

36. Takaoka RTC, Sertório ND, Magalini LPJ, Dos Santos LM, Souza HR, lyomasaPilon MM, et al. Expression profiles of Annexin A1, formylated peptide receptors and cyclooxigenase- 2 in gastroesophageal inflammations and neoplasias. Pathol Res Pract. 2018;214:181-6.

37. Kao W, Gu R, Jia Y, Wei X, Fan H, Harris J, et al. A formyl peptide receptor agonist suppresses inflammation and bone damage in arthritis. $\mathrm{Br} J$ Pharmacol. 2014;171:4087-96

38. Shimizu N, Tanaka A, Mori T, Hoque A, Jinno-Oue A, Apichartpiyakul C, et al A formylpeptide receptor, FPRL1, acts as an efficient coreceptor for primary isolates of human immunodeficiency virus. Retrovirology. 2008:5:52.

\section{Publisher's Note}

Springer Nature remains neutral with regard to jurisdictional claims in published maps and institutional affiliations.
Ready to submit your research? Choose BMC and benefit from:

- fast, convenient online submission

- thorough peer review by experienced researchers in your field

- rapid publication on acceptance

- support for research data, including large and complex data types

- gold Open Access which fosters wider collaboration and increased citations

- maximum visibility for your research: over $100 \mathrm{M}$ website views per year

At $\mathrm{BMC}$, research is always in progress.

Learn more biomedcentral.com/submissions 